Irina Juhas

Ana Orlić

Dušanka Lazarević

Nenad Janković

796-057.875:159.9.072

Milan Matić

Original Scientific Paper

Faculty of Sport and Physical Education, University of Belgrade

\title{
THE ATTITUDE OF THE FACULTY OF SPORT AND PHYSICAL EDUCATION STUDENTS TOWARD CROSS-COUNTRY RUNNING
}

\begin{abstract}
The syllabus of the track and field subject at the Faculty of Sport and Physical Education includes cross-country running - running in nature. The main objective of this study was to determine the structure and intensity of students' attitude toward the cross-country running. Besides, the objective was to check the connection of the students' attitude towards the cross-country running and the achieved results of cross-country running, as well as of doing sport and recreational running. The sample comprised 69 students of the second year of studies who attended the cross-country running classes. For measuring the attitude toward the cross-country running, the Connotative differential instrument was used consisting of 15 pairs of opposite adjectives presented in a form of seven-part bipolar scale grouped into three dimensions: affective, cognitive and conative. This instrument was applied within an extensive questionnaire which included questions about doing sports, jogging, as well as the results of cross-country running at the end of the teaching period. The descriptive analysis has shown that students have a positive attitude of moderate intensity toward cross-country running, observed through all three dimensions of attitude. The correlation analysis between the dimensions of attitude toward cross country running and the results achieved at cross country running showed that the correlations are negative and statistically significant, suggesting that if the result of running is better, the students' attitude toward cross country running is more positive. Competitive sport is not connected with the quality of attitude toward crosscountry running. The results obtained by the study give grounds for assuming that, given that attitudes are an important component of the motivational aspect of personality, it can be expected that the students' positive attitude toward cross country running would contribute to cross country running application in their future professional activity and encourage this form of physical activity.
\end{abstract}

Key words: TEACHING / CONNOTATIVE DIFFERENTIAL / RUNNING

\section{INTRODUCTION}

One of the efficient ways to eliminate the harmful consequences of sedentary way of life is to use running as a natural form of movement. Running provides the necessary quantities of oxygen to the body, improves heart and lungs function, activates blood circulation and metabolism, improves sleep, work ability, and plays an important role in health preservation (Stefanovic, Juhas, Jankovic, 2008). In addition, it has numerous positive psychological effects such as emotional tension and anxiety reduction as well as good general psychological condition (Weinberg \& Gould, 2007). With this in mind, it is important to develop interest in this type of physical activity in young people through the educational process, so that it would become an integral part of their daily lives as a component of a healthy lifestyle. A teacher of physical education and sport, who shall influence the development of these interests in young 
people with his/her professional knowledge, physical preparedness, and a positive attitude toward running, has an important role in it.

Because of its distinctive explanatory and predictive power, the term attitude is used in various fields of social sciences, both for theoretical and practical purposes. Among a number of definitions in this paper, we have chosen a definition according to which an attitude is "a permanent system of positive or negative assessment, feelings and tendencies to take action for or against - in relation to different objects" (Krech, Crutchfield \& Ballachey, 1972; according to Rot, 2003, p. 318). The complexity of attitudes has been in the foreground because of this definition, which means they also include cognitive, emotional, and connative component. Cognitive component of an attitude comprises knowledge and understanding about objects or phenomena to which there is an attitude, as well as value judgments for the object or phenomenon evaluated. The emotional component includes feelings related to the object of an attitude, which may be more or less complex. Conative component represents the tendency to take concrete action in relation to the object toward which there is an attitude. The expression "a permanent system" emphasizes the dispositional character of an attitude and its role in manifesting the relative consistency in the treatment of the object. Therefore, based on knowledge of attitudes toward specific objects, behaviour can be predicted with some degree of confidence. With this in mind, the knowledge of the structure and intensity of attitudes of the Faculty of Sport and Physical Education students to the various forms of physical exercise is important for predicting the quality of their future professional engagement.

Since 1983, the Faculty of Sport and Physical Education has developed a program of educating students for cross-country running application, as one of the methods for developing aerobic endurance (Stefanovic, Juhas, Jankovic \& Matic, 2009). In this study, the object of the research is the students' attitude toward cross-country running, since they, as experts in the field of physical education and sport, can affect the development of young people' interests toward this form of exercise with their positive attitude. Besides, a positive attitude toward crosscountry running can have effects on their success in running, on better understanding of running, and thus on their professional competence.
The main objective of this study was to determine the structure and intensity of the attitude of the Faculty of Sport Physical Education students toward cross-country running. Another aim was to verify the connection of students' attitude toward cross-country running and the results achieved in it. In addition, it was aimed at evaluating the relationship between attitude towards cross-country running and doing sports in general, and in particular towards recreational running.

\section{METHOD}

\section{Participants}

The study included 77 participants, the second year students of the Faculty of Sport and Physical Education, University of Belgrade, who were involved in cross-country running program within track and field classes. The final sample comprised 69 students (54 male and 15 female) who had a correctly completed questionnaire.

\section{Instrument}

Bearing in mind that, in this study, students' attitudes were studied after educationl program for cross-country running application, the approach for measuring attitudes based on the Osgood's semantic differential was chosen (Osgood, Succi and Tannenbaum, 1957). The semantic differential was designed to measure the connotative meaning of words in the 50's of the 20th century, and it proved to be a very solid technique for measuring attitudes towards different phenomena (Havelka, Kuzmanovic and Popadic, 1998). Recent studies conducted in our country, which start from the semantic differential technique, have resulted in constructing a new instrument, the connotative differential, the structure of which comprises affective, conative, and cognitive factor (Jankovic, 2000, a, b, c). Given that the structure of the attitude comprises exactly these three dimensions, this approach is considered to be suitable for research of attitudes as well.

Connotative differential is designed for quantitative measuring of the respondents' subjective perception toward the object of an attitude. This instrument consists of 15 pairs of opposite adjectives presented in a form of seven-step bipolar rating-scale of estima- 
tion (from -3 to 3 ). All adjectives are grouped into three dimensions. The first, affective dimension refers to the emotional-evaluative aspect of subjective experience, which consists of scales: unpleasant-pleasant, repulsive-attractive, disgusting-savory, bad-good and ugly-beautiful. The second, conative dimension refers to the motivational aspect of subjective experience, and comprises the scale unimpressive-impressive, uninspiring-inspiring, boring-interesting, unimportantimportant, and non-motivating-motivating. The last, cognitive dimension refers to the cognitive aspect of subjective experience and comprises the scale: meaningless-meaningful, incomprehensible-understandable, illogical-logical, unknown-known and unclearclear. Kaiser-Mayer-Olkin representativeness measurement of the connotative differential is 0.92 , and the reliability of certain dimensions (Cronbach $\alpha$ ) is 0.97 for the affective, 0.80 for the conative, and 0.86 for the cognitive dimension.

Connotative differential instrument is given within an extensive questionnaire which included the questions related to sports involvement (competitive and/or recreational), recreational running, as well as to the result that the students achieved at cross-country running at the end of the teaching period.

\section{Cross country running teaching characteristics}

Within the track and field classes, a program cross-country running has been implemented for a period of 6 weeks ( 2 hours per week) (Stefanovic, Juhas, Jankovic, 2007). The program was implemented in the period February-March 2010, on the cross-country running track in the Park Forest Košutnjak. At the beginning of implementation, the initial measurements were taken at a distance of $6,000 \mathrm{~m}$ for male students and $4,000 \mathrm{~m}$ for female students. Based on the results of initial measurements the individual program was made and it was carried out by each student. Specified loads at classes were in the zone which stimulated the development of aerobic energy potential - aerobic capacity. A student was required to monitor and record the following parameters of the load:

- pulse at the beginning, during and at the end of running,

- the length of the distance run,

- the number of repeated distances (volume)

- achieved time and

- duration of rest between the repetition of distances.
Each student wrote the accomplished values of these parameters into the Athletics Practicum, so as to analyze training later, aimed at knowing whether the given task was successfully accomplished. After the applied program, the final measurement was conducted within the competition, "Open championship of the Faculty of Sport and Physical Education in cross-country running".

\section{The research procedure}

Upon completion of the classes and the final measurements, the Questionnaire for measuring attitude toward the cross-country running was applied. The participants were instructed to circle one of the numbers on a scale from -3 to +3 for each of the following pairs of adjectives to express their personal, subjective experience of cross-country running, and then to answer the remaining questions. The research was realized with the voluntary consent of students and it was anonymous.

\section{Statistical methods}

Descriptive statistics procedures (mean, standard deviation, frequencies, and percentages) and statistical reasoning (Pearson correlation coefficient and t-test for independent samples) were used in the data analysis. The data were processed by SPSS 17.0 statistical software package.

\section{RESULTS AND DISCUSSION}

\section{The intensity and structure of attitude toward cross country running}

Starting from the basic research objectives related to the determination of the structure and intensity of attitude of the Faculty of Sport and Physical Education students toward cross-country running, a descriptive analysis of data obtained by connotative differential was performed. In the beginning, the scale from -3 to +3 was transformed into a scale from 1 to 7, for the possibility of statistical analysis as required by data processing statistical software; so that the value -3 corresponds to the value 1 , and the value 7 corresponds to the value +3 . The means and standard deviations for all three dimensions of Connotative differential are given in Graph 1. 
Graph 1 Means and standard deviations for affective, conative, and cognitive dimensions of the semantic differential

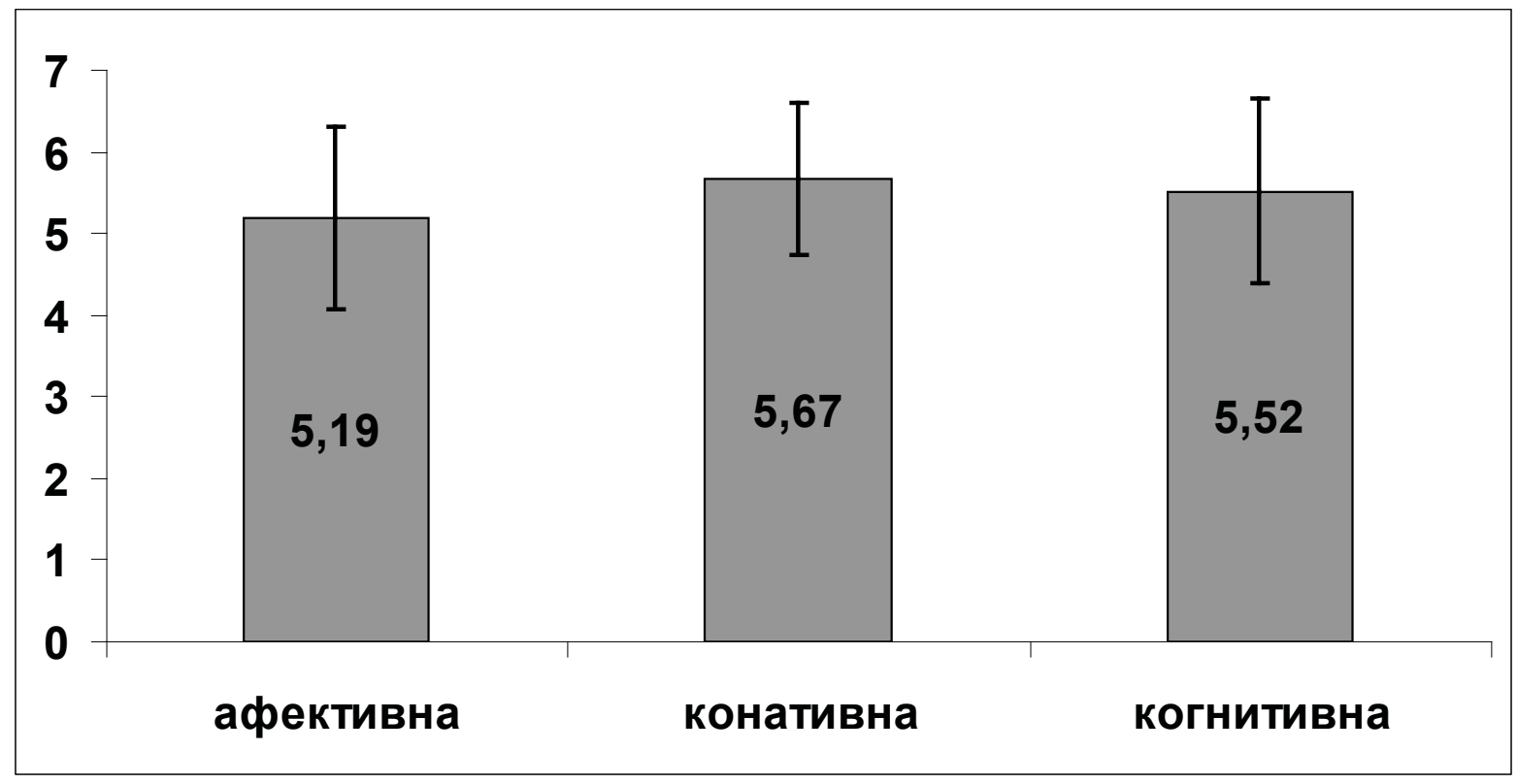

From the Graph 1 it can be seen that students, in general, have a positive attitude of moderate intensity toward cross-country running. The mean value for the affective dimension is $5.19 \pm 1.12$, for conative $5.67 \pm 0.94$ and for cognitive 5:52 \pm 1.13 , which means that the results for all three dimensions are relatively uniform. In other words, students assess cross-country running as something that is emotionally positive to them, what they like, what motivates them to be active and what is close and familiar to them. The obtained values which indicate that the students of the Faculty of Sport and Physical Education showed a moderate, but not a distinctively positive attitude, can be regarded as expected, given that cross-country running as an object of attitude does not belong to a group of phenomena, such as significant social ones, to which people most often have very intensively pronounced attitudes. A positive attitude of students toward cross-country running, in which all three components (emotional, conative and cognitive), are unified by the degree of expression, suggests that one can expect that they will be ready to apply cross-country running in their professional work and to motivate users for this form of running.

\section{The connection of attitude toward cross-} country running and the success in running

To check the connection of the respondents' attitude towards cross-country running and the achieved result at the end of the classes, the analysis of correlations between all three attitude dimensions and the time that students have achieved in the running has been done. Pearson correlation coefficients and their statistical significance are shown in Table 1.

Table 1 Height and significance of the correlation coefficient between the results achieved in cross-country running, and all three dimensions of Connotative differential

\begin{tabular}{lll}
\hline & & \\
H & $\begin{array}{c}\text { Пирсонов коефицијент } \\
\text { корелације (r) }\end{array}$ \\
\hline Резултат / афективна димензија & 69 & -0.27 \\
Резултат / конативна димензија & -0.32 \\
Резултат / когнитивна димензија & & -0.31 \\
\hline
\end{tabular}


From Table 1 it can be seen that the correlation coefficients for all three dimensions of attitude and the results in running are negative and statistically significant. The correlation between the affective dimension and the results of running is -0.27 and is significant at the 0.05 level, between the conative dimension and the results of running is -0.32 and is significant at the 0.01 level and between the cognitive dimensions and the results is -0.31 and is significant at the 0.01 level. Such correlations indicate that the shorter time that students have achieved in running, or the better their result is, the more positive their attitude is toward cross-country running at the level of all three components. This is in concordance with the results of research on the importance of positive attitudes for success in certain sport activities (Havelka and Lazarevic, 1981) and willingness to engage in it.

\section{Attitude toward cross-country running and doing sports}

The third objective of this study was to investigate whether there was a correlation between the attitude toward cross-country running and doing sports, competitive and/or recreational, as well as practicing recreational running. The results of answers to these questions are presented in Table 2.

Table 2 Percentage of respondents' answers to questions whether they compete in sports, whether they do sports recreationally and whether they practice recreational running

\begin{tabular}{lcc}
\hline & Одговори & Проценат \\
\hline Бављење спортом & да & $45 \%$ \\
такмичарски & не & $55 \%$ \\
\hline Бављење спортом & да & $91 \%$ \\
рекреативно & не & $9 \%$ \\
\hline Бављење трчањем & да & $90 \%$ \\
рекреативно & не & $10 \%$ \\
\hline
\end{tabular}

Table 2 shows that the percentage of respondents who compete in sports is smaller compared to those who are not involved (45\% compete, while $55 \%$ do not). T-test for independent samples showed that there was no statistically significant difference in the subjective experience of running in nature of any of the Connotative differential dimensions between the students who compete in sports and those who are not involved in them. From this, it can be concluded that competitive sport is not connected with the quality of attitude toward cross-country running.

Students had the opportunity to express in the questionnaire whether they do recreational sports in the addition to the competitive. Most of them (91\%) stated that they do recreation sport. Recreational running, according to students, is practiced by $90 \%$ of them. Such structure of results does not provide the basis for statistical testing of differences in attitudes toward cross-country running.

\section{CONCLUSION}

In this paper, the attitude of students of the Faculty of Sport and Physical Education toward cross-country running was examined using the Connotative differential. The study included 69 students (54 males and 15 females) in the second year of the Faculty of Sport and Physical Education who were involved in cross-country running within the athletics classes. The results showed that students have a positive attitude of moderate intensity toward this form of physical activity. The data on the connection of attitude intensity and success in cross-country running obtained in this study support the findings of positive attitude importance for succeeding in a certain activity. Bearing in mind that attitudes represent an important component of the motivational aspect of personality (they encourate action and engagement), it can be expected that the positive attitude of students toward cross-country running shall contribute to their willingness to apply cross-country running and encourage students to practice this very attractive form of physical activity in nature in their future professional activity, especially as PE teachers. Observed in the long-run, this can contribute to the development of a healthy lifestyle.

The classes in which students are trained to use cross-country running or running in nature, as methods for developing aerobic endurance, by its contents and methodological approach, can be considered suitable for developing a positive attitude towards this form of physical activity. The individualization of teaching process and a high level of students' involvement in monitoring their own progress can particularly be emphasized. In future research the focus 
should be on more precise monitoring of direct teaching effects on the formation of students' attitude toward cross-country running, but also on longer-term effects of education on this kind of running application in their future professional work.

\section{REFERENCES}

1. Janković, D. (2000a). Konotativni aspekt značenja: utvrđivanje latentnih dimenzija. [Connotative aspect of meaning: determination of latent dimensions]. Psihologija, 33(1-2), 199221.

2. Janković, D. (2000b). Konotativni aspekt značenja: konstrukcija konotativnog diferencijala [Connotative aspect of meaning: construction of connotative differential]. Psihologija, 33(1-2), 221- 239.

3. Janković, D. (2000c). Konotativni aspekt značenja: utvrđivanje bazičnih dimenzija i konstrukcija konotativnog diferencijala. [Connotative aspect of meaning: determination of basic dimensions and construction of connotative differential]. Diplomski rad [Graduate thesis]. Beograd: Filozofski fakultet.

4. Osgood, C., Succi, G.J., \& Tannenbaum, P. (1957). The measurement of meaning. Urbana: University of Illinois Press.

5. Rot, N. (2003). Osnovi socijalne psihologije. [Basis of social psychology]. Beograd: Zavod za udžbenike i nastavna sredstva.

6. Stefanović, Đ., Juhas, I., i Janković, N. (2007). Praktikum atletike. [Lab of athletic]. Beograd: Fakultet sporta i fizičkog vaspitanja
The article was carried out within the projects: „The identification, measurement and development of cognitive and emotional competencies important society oriented to European integration” No. 179018 and „Effects of physical activity applied to locomotion, metabolic, psycho-social and educational status of the population of R Serbia" No. III47015, as part of a sub-project „Effects of applied physical activity on psycho-social and educational status of the university population of R Serbia", funded by the Ministry of Science and Technology of Republic Serbia - The cycle of scientific projects, 2011-2014.

7. Stefanović, Đ., Juhas, I., i Janković, N. (2008). Teorija $i$ metodika atletike. [Theory and methodic of athletic]. Beograd: Fakultet sporta $\mathrm{i}$ fizičkog vaspitanja.

8. Stefanovic, Dj., Juhas, I., Jankovic, N., i Matic, M. (2010). Cross in function of education of students for healthy life style. In S. Stojiljkovic \& M. Dopsaj (Eds). FISU Conference 25th Universiade. Proceedings. The role of university sports in education and society - a platform for change (pp. 51-54). Belgrade: Faculty of Sport and Physical Education.

9. Havelka, N., Kuzmanović, B., i Popadić, D. (1998). Metode i tehnike socijalnopsiholoških istraživanja. [Methods and techniques of socialpsychology researches]. Beograd: Centar za primenjenu psihologiju Društva psihologa Srbije.

10. Havelka, N., i Lazarević, LJ. (1981). Sport $i$ ličnost. [Sport and personality]. Beograd: Sportska knjiga.

11. Weinberg, R.S., \& Gould, D. (2007). Foundations of sport and excercise psychology (4thed.). Champaign: Human Kinetics. 
Ирина Јухас

Ана Орлић

Душанка Лазаревић

Ненад Јанковић

796-057.875:159.9.072

Милан Матић

Изворни научни чланак

Факултет спорта и физичког васпитања, Универзитет у Београду

\title{
СТАВ СТУДЕНАТА ФАКУЛТЕТА СПОРТА И ФИЗИЧКОГ ВАСПИТАЫА ПРЕМА КРОСУ
}

\begin{abstract}
Сажетак
На Факултету спорта и физичког васпитања се у програму наставе атлетике налази и крос, трчање у природи. Основни циљ овог истраживања је био да се утврди структура и интензитет става студената према кросу. Такође, циљ је био да се провери повезаност става студената према кросу и постигнутог резултата у трчању кроса, као и бављења спортом и рекреативним трчањем. Узорак је чинило 69 студената, друге године студија, који су похађали програм наставе из кроса. За мерење става према кросу коришћен је инструмент Конотативни диференцијал који се састоји од 15 парова опозитних придева представљених у форми седмочланих биполарних скала процене груписаних у три димензије: афективну, когнитивну и конативну. Овај инструмент је дат у оквиру ширег упитника у који су била укључена питања о бављењу спортом, рекреативним трчањем, као и о резултату на кросу на крају наставног периода. Дескриптивна анализа је показала да студенти према кросу имају позитиван став умереног интензитета, посматрано преко све три димензије става. Анализа корелација између димензија става испитаника према кросу и постигнутог резултата на кросу показала је да су корелације негативне и статистички значајне, што указује да што је резултат трчања бољи, став студената према кросу је позитивнији. Такмичарско бављење спортом није повезано са квалитетом става према кросу. Добијени резултати у овом истраживању дају основе за претпоставку да се, с обзиром да ставови представљају важну компоненту мотивационе сфере личности, може очекивати да ће позитиван став студената према кросу допринети да у будућем професионалном ангажовању примењују крос и подстичу на овај вид физичке активности.
\end{abstract}

Кључне речи: НАСТАВА / КОНОТАТИВНИ ДИФЕРЕНЦИЈАЛ / ТРЧАњЕ

\section{УВОД}

Један од ефикасних начина отклањања штетних последица седентарног начина живота је коришћење трчања, као природног облика кретања. Трчање организму обезбеђује потребне количине кисеоника, побољшава рад срца и плућа, активира крвоток и метаболизам, побољшава сан, радну способност и игра значајну улогу у очувању здравља (Стефановић, Јухас, Јанковић, 2008). Такође, оно има многобројне психолошке позитивне ефекте као што су смањење емо- ционалне напетости, анксиозности и добро опште психолошко стање (Weinberg \& Gould, 2007). Имајући ово у виду, важно је кроз образовни процес развијати код младих интересовања за овај облик физичке активности, како би он постао саставни део њихове свакодневице, као компонента здравог стила живота. У томе значајну улогу има професор физичког васпитања и спорта који ће својим стручним знањем, физичком припремљеношћу, али и позитивним ставом пре- 
Јухас И., и сар., Став студената факултета спорта... ФИЗИЧКА КУЛТУРА 2011; 65 (1): 46-51

ма трчању утицати на развој ових интересовања код младих.

Због своје изражене експланаторне и предиктивне снаге појам става се користи у разним областима друштвених наука, како у теоријске, тако и у практичне сврхе. Између већег броја дефиниција у овом раду смо се определили за дефиницију по којој су ставови „трајни системи позитивног или негативног оцењивања, осећања и тенденције да се предузме акција за или против - а у односу на различите објекте“ (Krech, Crutchfield \& Ballachey, 1972, према Рот, 2003, стр. 318). Ова дефиниција ставља у први план сложеност ставова, што значи да они истовремено укључују и когнитивну и емоционалну и конативну компоненту. Когнитивну компонету става чине знања и схватања о објектима или појавама према којима постоји став, као и вредносни судови којима се објекти или појаве евалуирају. Емоционална компонента укључује осећања везана за објекат става која могу бити мање или више сложена. Конативна компонента представља тенденцију да се предузме конкретна акција у односу на објекат према коме постоји став. Изразом „трајни систем“ наглашава се диспозициони карактер става и његова улога у испољавању релативне доследности у понашању према објекту. Дакле, на основу познавања ставова према одређеним објектима може се са извесним степеном поузданости предвиђати понашање. Имајући ово у виду, познавање структуре и интензитета ставова студената Факултета спорта и физичког васпитања према различитим облицима физичког вежбања значајно је за предвиђање квалитета њиховог будућег професионалног ангажовања.

На Факултету спорта и физичког васпитања се од 1983. одржава програм едукације студената за примену кроса, као једног од метода за развој аеробне издржљивости (Stefanovic, Juhas, Jankovic \& Matic, 2009). У овом раду, предмет истраживања је став студената према кросу, с обзиром на то да они као стручњаци у области физичког васпитања и спорта својим позитивним ставом могу да утичу на развој интересовања младих према овом облику физичке активности. Поред тога, позитиван став према кросу може да има ефекте на њихову успешност у трчању, на боље разумевање феномена трчања, а самим тиме и на њихове професионалне компетенције.
Основни циљ истраживања је био да се утврди структура и интензитет става студената Факултета спорта и физичког васпитања према кросу. Такође, циљ је био да се провери повезаност става студената према кросу и постигнутог резултата у трчању кроса. И треће, циљ је био да се провери однос између става према кросу и бављења спортом, уопште, и рекреативним трчањем посебно.

\section{МЕТОД}

\section{Испитаници}

У истраживању је учествовало 77 испитаника, студената друге године Факултета спорта и физичког васпитања Универзитета у Београду, који су у оквиру наставе атлетике били укључени у програм трчања кроса. Коначни узорак чинило је 69 студената (54 мушког и 15 женског пола) који су имали коректно попуњен упитник.

\section{Инструмент}

Имајући у виду да су у овом раду испитивани ставови студената након програма едукације за примену кроса, изабран је приступ у мерењу ставова који полази од Озгудовог семантичког диференцијала (Osgood, Succi i Tannenbaum, 1957). Семантички диференцијал је 50-их година 20. века конструисан за мерење конотативног значења речи, а показао се и као веома солидна техника за мерење ставова према различитим феноменима (Хавелка, Кузмановић и Попадић, 1998). Истраживања новијег датума спроведена у нашој средини, која полазе од технике семантичког диференцијала, резултирала су конструисањем новог инструмента, Конотативног диференцијала, чију факторску структуру чине афективни, конативни и когнитивни фактор (Јанковић, 2000, а, б, ц). С обзиром на то да структуру става чине управо ове три димензије, сматра се да је овај приступ погодан и за истраживања у области ставова.

Конотативни диференцијал је конструисан за квантитативно мерење субјективног доживљаја испитаника према објекту става. Овај инструмент се састоји од 15 парова опозитних придева представљених у форми седмочланих бипо- 
ларних скала процене (од -3 до 3). Сви придеви груписани су у три димензије. Прва, афективна димензија односи се на емотивно-евалуативни аспект субјективног доживљаја, а чине је скале: непријатно-пријатно, одбојно-привлачно, мрско-драго, лоше-добро и ружно-лепо. Друга, конативна димензија односи се на мотивациони аспект субјективног доживљаја, а чине је скале неупечатљиво-упечатљиво, неподстицајноподстицајно, досадно-занимљиво, небитнобитно и немотивишуће-мотивишуће. Последња, когнитивна димензија односи се на сазнајни аспект субјективног доживљаја и чине је скале: бесмислено-смислено, неразумљиво-разумљиво, нелогично-логично, непознато-познато и нејасноjacнo. Kaiser-Mayer-Olkin мера репрезентативности Конотативног диференцијала износи 0.92, а поузданост појединих димензија (Cronbach $\alpha$ ) износи 0.97 за афективну, 0.80 за конативну и 0.86 за когнитивну димензију.

Инструмент Конотативни диференцијал дат је у оквиру ширег упитника у који су била укључена питања која су се односила на бављење спортом (такмичарско и/или рекреативно), рекреативно бављење трчањем, као и на резултат који су студенти постигли на кросу на крају наставног периода.

\section{Карактеристике наставе кроса}

У оквиру наставе атлетике примењен је програм трчања кроса у трајању од 6 недеља (2 часа недељно) (Стефановић, Јухас, Јанковић, 2007). Програм је спроведен у временском периоду фебруар-март 2010. године, на стази за трчање кроса, у парк-шуми Кошутњак. На почетку примене програма изведено је иницијално мерење на дистанци од $6.000 \mathrm{~m}$ за студенте и $4.000 \mathrm{~m}$ за студенткиње. На основу резултата иницијалног мерења направљен је индивидуални програм, који је сваки студент реализовао. Задата оптерећења на часовима су била у зони која је стимулисала развој аеробног енергетског потенцијала - аеробни капацитет. Студент је био обавезан да прати и забележи следеће параметре оптерећења:

- пулс на почетку, током и на крају трчања,

- дужину претрчане дистанце,

- број понављајућих дистанци (обим),

- остварено време и

- трајање одмора између понављања дистанци.

Остварене вредности наведених парамета- ра студент је уписивао у Практикум из атлетике, како би касније могао да изврши анализу тренинга, а све у циљу сазнања да ли је успешно остварио постављени задатак. После примењеног програма спроведено је финално мерење које је спроведено у оквиру такмичења „Отворено првенство Факултета спорта и физичког васпитања у кросу“.

\section{Поступак у истраживању}

По завршетку наставе и финалног мерења примењен је Упитник за мерење става према кросу. Испитаници су добили упутство да заокружујући један од бројева на скали од -3 до +3 за сваки од понуђених парова придева изразе свој лични, субјективни доживљај кроса, а затим да одговоре на преостала питања. Испитивање је реализовано уз добровољни пристанак студената и било је анонимно.

\section{Статистичке методе}

У анализи података примењени су поступци дескриптивне статистике (аритметичка средина, стандардна девијација, фреквенце и проценти) и статистике закључивања (Пирсонов коефицијент корелације и т-тест за независне узорке). Подаци су обрађени статистичким пакетом SPSS 17.0.

\section{РЕЗУЛТАТИ И ДИСКУСИЈА}

\section{Интензитет и структура става према кросу}

Полазећи од основног циља истраживања који се односи на утврђивање структуре и интензитета става студената Факултета спорта и физичког васпитања према кросу, извршена је дескриптивна анализа података добијених Конотативним диференцијалом. На почетку је скала од -3 до +3 трансформисана у скалу од 1 до 7, ради могућности статистичке обраде према захтевима статистичког програма за обраду података, тако да вредност -3 одговара вредности 1, а вредност +3 одговара вредности 7. Аритметичке средине и стандардне девијације, за све три димензије Конотативног диференцијала, дате су у Графикону 1. 
Графикон 1 Аритметичке средине и стандардне девијације за афективну, конативну и когнитивну димензију семантичког диференцијала

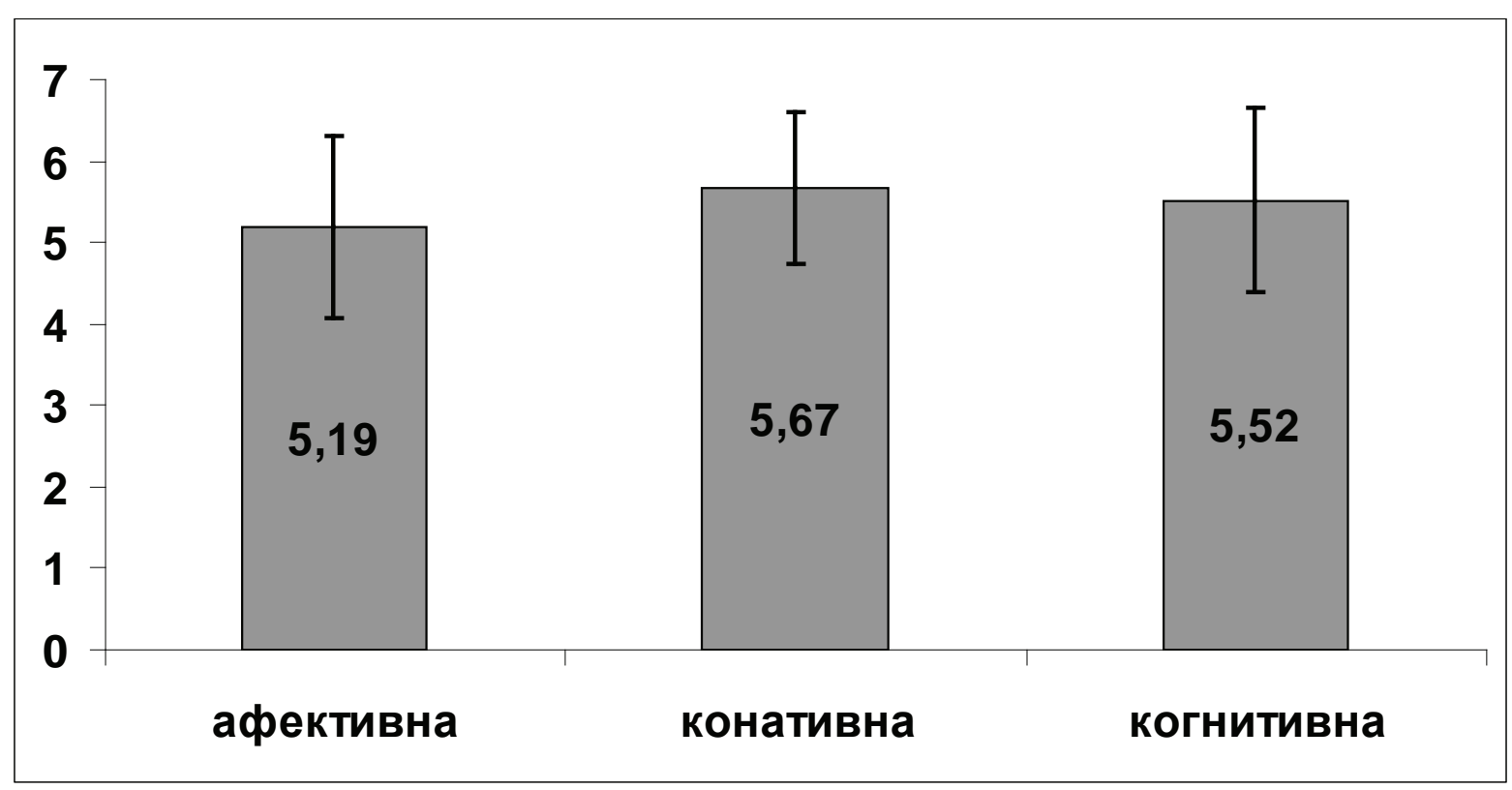

Из Графикона 1 може се видети да студенти, у целини гледано, имају позитиван став умереног интензитета према кросу. Средња вредност за афективну димензију износи $5.19 \pm 1.12$, за конативну $5.67 \pm 0.94$ и за когнитивну $5.52 \pm 1.13$, што значи да су резултати за све три димензије релативно уједначени. Другим речима, студенти крос процењују као нешто што је њима емотивно позитивно, што воле, што их мотивише на активност и што им је блиско и познато. Добијене вредности које указују да су студенти Факултета спорта и физичког васпитања испољили умерено, а не изразито позитиван став, се може сматрати очекиваним, с обзиром на то да крос, као објект става, не припада групи феномена према којима људи најчешће имају ставове веома израженог интензитета, као што су неке значајне друштве- не појаве. Позитиван став студената према кросу, у коме су све три компоненте (емотивна, конативна и когнитивна) уједначене по степену изражености, указује на то да се може очекивати да ће они бити спремни да у свом стручном раду примењују крос и да мотивишу кориснике за овај облик трчања.

\section{Повезаност става према кросу и успеха у трчањy}

Да би се проверила повезаност става испитаника према кросу и постигнутог резултата на крају наставе приступило се анализи корелација између све три димензије става и времена које су студенти постигли у трчању. Пирсонови коефицијенти корелације и њихова статистичка значајност приказани су у Табели 1.

Табела 1 Висина и значајност коефицијента корелације између постигнутог резултата у трчању кроса и све три димензије Конотативног диференцијал

\begin{tabular}{lccc}
\hline & H & $\begin{array}{c}\text { Пирсонов } \\
\text { коефицијент } \\
\text { корелације (r) }\end{array}$ & $\begin{array}{c}\text { Значајност } \\
\text { коефицијента } \\
\text { корелације }\end{array}$ \\
\hline Резултат / афективна димензија & 69 & -0.27 & .024 \\
Резултат / конативна димензија & -0.32 & .007 \\
Резултат / когнитивна димензија & -0.31 & .009 \\
\hline
\end{tabular}


Јухас И., и сар., Став студената факултета спорта... ФИЗИЧКА КУЛТУРА 2011; 65 (1): 46-51

Из Табеле 1 може се видети да су кое= фицијенти корелације за све три димензије става и резултата у трчању негативни и статистички значајни. Корелација између афективне димензије и резултата у трчању износи -0.27 и значајна је на нивоу 0.05 , између конативне димензије и резултата трчања износи -0.32 и значајна је на нивоу 0.01 и између когнитивне димензије и резултата износи -0.31 и значајна је на нивоу 0.01 . Овакве корелације говоре о томе да што је време које су студенти постигли у трчању мање, односно што је резултат бољи, њихов став према кросу је на нивоу све три компоненте позитивнији. Ово је у сагласности са резултатима истраживања о значају постојања позитивних ставова за успешност у одређеној спортској активности (Хавелка и Лазаревић, 1981) и спремности за ангажовање у њој.

\section{Став према кросу и бављење спортом}

Трећи циљ овог истраживања био је да се испита да ли постоји повезаност између става према кросу и бављења спортом, такмичарски и/или рекреативно, као и рекреативног бављења трчањем. Резултати одговора на ова питања приказани су у Табели 2.

Табела 2 Проценти одговора испитаника на питања да ли се такмичарски баве спортом, да ли се рекреативно баве спортом и да ли се рекреативно баве трчањем

\begin{tabular}{lcc}
\hline & Одговори & Проценат \\
\hline Бављење спортом & да & $45 \%$ \\
такмичарски & не & $55 \%$ \\
\hline Бављење спортом & да & $91 \%$ \\
рекреативно & не & $9 \%$ \\
\hline Бављење & да & $90 \%$ \\
трчањем & некреативно & $10 \%$ \\
\hline
\end{tabular}

Табела 2 показује да је проценат испитаника који се такмичарски баве спортом мањи у односу на оне који се не баве (45\% се бави, а $55 \%$ се не бави). Т-тест за независне узорке је показао да не постоји статистички значајна разлика у субјективном доживљају трчања у природи ни за једну од димензија Конотативног диференцијала између студената који се такмичарски баве спортом и оних који се не баве. Из овога се може закључити да такмичарско бављење спортом није повезано са квалитетом става према кросу.

Студенти су имали прилику да се у упитнику изјасне да ли се поред такмичарског и рекреативно баве спортом. Већина њих (91\%) наводи да се рекреативно бави спортом. Рекреативним трчањем, према изјавама студената, бави се њих 90\%. Оваква структура резултата не даје основу за статистичку проверу разлика у ставовима према кросу.

\section{ЗАКЉУЧАК}

У овом раду испитиван је став студената Факултета спорта и физичког васпитања према кросу, применом Конотативног диференцијала. У истраживању је учествовало 69 студената (54 мушког и 15 женског пола) друге године Факултета спорта и физичког васпитања који су у оквиру наставе атлетике били укључени у програм трчања кроса. Резултати су показали да студенти имају позитиван став умереног интензитета према овом облику физичке активности. Податак о повезаности интензитета става и успешности у трчању кроса добијен у овом истраживању иде у прилог сазнања о важности постојања позитивних ставова за успешност у одређеној активности. Имајућу у виду да ставови представљају важну компоненту мотивационе сфере личности (подстичу на акцију и ангажовање), може се очекивати да ће позитиван став студената према кросу допринети њиховој спремности да, у свом будућем професионалном ангажовању, нарочито као професори физичког васпитања, примењују крос и подстичу ученике да се баве овим веома атрактивним видом физичке активности у природи. Дугорочније посматрано, ово може да допринесе развоју здравог стила живота.

Настава у оквиру које су студенти едуковани за примену кроса, односно трчања у природи, као методе за развој аеробне издржљивости, по својим садржајима и методичком приступу, може се сматрати погодном за развијање позитивног става према овом виду физичке активности. Посебно се може истаћи индивидуализација наставног процеса и висок степен укључености 
студената у праћење сопственог напретка. У наредним истраживањима требало би се усмерити на прецизније праћење непосредних ефеката наставе на формирање става студената према кросу, али и дугорочнијих ефеката наставе на примену овог облика трчања у њиховом будућем професионалном раду.

\section{ЛИТЕРАТУРА}

1. Јанковић, Д. (2000а). Конотативни аспект значења: утврђивање латентних димензија. Психологија, 33(1-2), 199- 221.

2. Јанковић, Д. (2000б). Конотативни аспект значења: конструкција конотативног диференцијала. Психологија, 33(1-2), 221- 239.

3. Јанковић, Д. (2000ц). Конотативни аспект значења: утврђивање базичних димензија и конструкција конотативног диференцијала. Дипломски рад. Београд: Филозофски факултет.

4. Osgood, C., Succi, G.J., \& Tannenbaum, P. (1957). The measurement of meaning. Urbana: University of Illinois Press.

5. Рот, Н. (2003). Основи соиијалне психологије. Београд: Завод за уџбенике и наставна средства.

6. Стефановић, Ђ., Јухас, И., и Јанковић, Н. (2007). Практикум атлетике. Београд: Факултет спорта и физичког васпитања
Рад је реализован у оквиру пројеката: „Идентификација, мерење и развој когнитивних и емоционалних компетенција важних друштву оријентисаном на европске интеграције” ев. број 179018 и „Ефекти примењене физичке активности на локомоторни, метаболички, психо-социјални и васпитни статус популације Р Србије“ ев.број III47015, а као део подпројекта “Ефекти примењене физичке активности на психо-социјални и васпитни статус универзитетске популације Р Србије”, које финансира Министарство за науку и технолошки развој Р Србије - Циклус научних пројеката 2011-2014.

7. Стефановић, Ђ., Јухас, И., и Јанковић, Н. (2008). Теорија и методика атлетике. Београд: Факултет спорта и физичког васпитања.

8. Stefanovic, Dj., Juhas, I., Jankovic, N., i Matic, M. (2010). Cross in function of education of students for healthy life style. In S. Stojiljkovic \& M. Dopsaj (Eds). FISU Conference 25th Universiade. Proceedings. The role of university sports in education and society - a platform for change (pp. 51-54). Belgrade: Faculty of Sport and Physical Education.

9. Хавелка, Н., Кузмановић, Б., и Попадић, Д. (1998). Методе и технике сочијалнопсихолошких истраживања. Београд: Центар за примењену психологију Друштва психолога Србије.

10. Хавелка, Н., и Лазаревић, љ. (1981). Спорт и личност. Београд: Спортска књига.

11. Weinberg, R.S., \& Gould, D. (2007). Foundations of sport and excercise psychology $\left(4^{\text {th }}\right.$ ed.). Champaign: Human Kinetics. 